\title{
RIGHTS AS TRUMPS AND BALANCING: RECONCILING THE RRECONCILABLE? *
}

\section{ABSTRACT}

THERE APPEARS TO BE A WIDESPREAD ASSUMPTION AMONG THOSE WHO DEFEND BALANCING IN CONSTITUTIONAL RIGHTS THAT IT IS INCOMPATIBLE WITH THE IDEA OF RIGHTS AS TRUMPS, BECAUSE PUBLIC INTERESTS AND CONSTITUTIONAL RIGHTS ARE TO BE BALANCED WITHOUT ANY TYPE OF PRE-FIXED PRIORITY OR LEXICAL ORDERING. MY PURPOSE IN THIS ARTICLE IS TO SHOW THAT BOTH TRUMPING AND BALANCING ARE NOT ONLY COMPATIBLE, BUT POSSIBLY COMPLEMENTARY. WHAT I WILL ARGUE IS THAT IT IS NOT ONLY POSSIBLE TO HAVE A WORKABLE ARRANGEMENT OF CONSTITUTIONAL RIGHTS THAT INCORPORATES BOTH TRUMPING AND BALANCING, BUT IT IS ALSO BETTER AND MORE PLAUSIBLE IF WE HAVE ONE.

\section{KEYWORDS}

TRUMPS; BALANCING; CONSTITUTIONAL RIGHTS; LEXICAL PRIORITY.

\author{
João Costa-Neto \\ OS DIREITOS COMO TRUNFOS E O SOPESAMENTO: \\ RECONCILIANDO O IRRECONCILIÁVEL?
}

\section{RESUMO}

UMA PREMISSA PARECE TER-SE DIFUNDIDO ENTRE OS DEFENSORES DO SOPESAMENTO DE DIREITOS FUNDAMENTAIS: A PREMISSA DE QUE O SOPESAMENTO SERIA INCOMPATIVEL COM A IDEIA DE DIREITOS COMO TRUNFOS. ISSO PORQUE OS INTERESSES PÚBLICOS E OS DIREITOS FUNDAMENTAIS DEVERIAM SER SOPESADOS SEM QUALQUER TIPO DE PRIORIDADE FIXA OU ORDENAÇÃO LEXICAL. O PROPÓSITO DESTE ARTIGO É MOSTRAR QUE O SOPESAMENTO E O CARÁTER DE TRUNFO DOS DIREITOS SÃO NÃO APENAS COMPATIVIEIS, MAS TAMBÉM COMPLEMENTARES.

DEFENDE-SE, POIS, QUE SE PODE CONCEBER UMA ESTRUTURA DE DIREITOS FUNDAMENTAIS QUE INTEGRE A IDEIA DE TRUNFO E O SOPESAMENTO; E QUE É MELHOR E MAIS PLAUSIVEL QUE ADOTEMOS ESSA ESTRUTURA.

\section{PALAVRAS-CHAVE}

TRUNFOS; SOPESAMENTO; DIREITOS FUNDAMENTAIS; PRIORIDADE LEXICAL.

\section{INTRODUCTION}

There appears to be a widespread assumption among those who defend balancing in constitutional rights that it is incompatible with the idea of rights as trumps, because public interests and constitutional rights are to be balanced without any type of prefixed priority or lexical ordering. ${ }^{1}$ My purpose in this article is to show that both trumping and balancing are not only compatible, but possibly complementary. What 
I will argue is that it is not only possible to have a workable arrangement of constitutional rights that incorporates both trumping and balancing, but it is also better and more plausible if we have one.

This article is organized as follows. First, I briefly review Dworkin's account on the concept of trumps (section 1). Next, I try to show why trumps have exceptions, even in Dworkin's view and even if they sometimes seem to be absolute, so that no trump is an ace of trumps (i.e. insurmountable or insuperable) (section 2). There follows a very broad outline of what balancing is and a short rebuttal of some criticisms of balancing (section 3). I then attempt to show that trumping and balancing are not only compatible, but complementary (section 4) and clarify in part the important relations between trumps, promises and constitutional rights (section 5). Furthermore, I hope to have demonstrated how important is the difference between the internal and the external theory to explain trumps and constitutional rights, indicating the fact that Dworkin presupposes that trumps are very clear and neat concepts, and showing how this might be a very serious shortcoming of Dworkin's theory, closely associated with his view of Law as integrity (section 7). A few refinements on the compatibility of trumping and balancing are then presented, including the notion of exclusionary reasons and promising, and the importance of public interests in balancing (section 8). Finally, I sustain the view that balancing can sufficiently help safeguard constitutional rights, and that it is in many ways similar to logic, in the sense that the soundness of its results ultimately depends on the truth of the assumed premises (section 9). The last section presents my conclusions.

\section{What ARE TRUMPs? A Brief Review of DwORKIN's ACCOUNT}

In Taking Rights Seriously, Ronald Dworkin develops his idea of rights as trumps. His main idea is that there are some moral rights against Government. According to him, not all Constitutional rights represent such moral rights, "[b]ut those Constitutional rights that we call fundamental like the right of free speech, are supposed to represent rights against the Government in the strong sense; that is the point of the boast that our legal system respects the fundamental rights of the citizen" (DWORKIN, 1977, p. 191).

This means that governments would do wrong to repeal such fundamental rights, even if they were persuaded that the majority would be better off that way (idem). Certain interests of individuals are so important that it would be wrong for the community "to sacrifice those interests just to secure an overall benefit" (DWORKIN, 2006, p. 31). Some rights, which can be called political or fundamental rights, "mark off and protect" these important individual interests. Such a right "is a trump over the kind of trade-off argument that normally justifies political action" (idem). The moral intuition behind this view seems to be that some individual liberties are so important 
that they cannot simply be disregarded on consequentialist grounds, even if the majority agrees to do so. In one sense, therefore, we are talking about a form of the "priority of the right over the good” (RAWLS, 1993, p. $173 \mathrm{f}$.).

In Justice for Hedgehogs, the last book by Dworkin published in his lifetime, he maintains his core ideas, ${ }^{2}$ saying that "policy is normally justified, for instance, if it would make the community safer by reducing violent crime: that is a good all-thingsconsidered justification for increasing taxes to pay for more police" (DWORKIN, 2011, p. 329).

The point of having trumps, on Dworkin's account, is precisely that they are not subject to being weighed. If the relevance of fundamental rights can be weighed at every new upcoming factual scenario and like any other social interest, then balancing "is a confusion that threatens to destroy the concept of individual rights" (DWORKIN, 1977, p. 199). For him, balancing is a confusion because it allegedly involves the competing rights of the individual and demands of society (ibidem, p. 197-198), which means it ultimately relies on an error.

Trumps are rights in a strong sense and that can only be said of certain fundamental and individual rights against Government, not of social and collective interests. In other words, once a certain priority in favor of a right is established and the Government defines it as fundamental, society should bear the collective costs that arise from it (DWORKIN, 1977, p. 198).

On this view, "[i]t cannot be an argument for curtailing a right, once granted, simply that society would pay a further price for extending it” (DWORKIN, 1977, p. 200). There must be something special about the cost that generates the restriction or limitation of a fundamental right, "or there must be some other feature of the case, that makes it sensible to say that although great social cost is warranted to protect the original right, this particular cost is not necessary" (idem).

The question that appears to emerge is what exceptions does trumping admit? In other words, what possible justifications, if any, may warrant the restriction or limitation of a trump?

\section{EXCEPTING TRUMPS}

Although a fundamental right trumps most welfare and consequentialist considerations, it does not mean, according to Dworkin himself, "that the State is never justified in overriding that right" (DWORKIN, 1977, p. 191). Someone might say the Government may override the right to free speech, for example, "when necessary to protect the rights of others, or to prevent a catastrophe, or even to obtain a clear and major public benefit (though if he acknowledged this last as a possible justification he would be treating the right in question as not among the most important or fundamental). What he cannot do is say that the Government is justified in overriding a 
right on the minimal grounds that would be sufficient if no such right existed" (ibidem, p. 191-192).

In Taking Rights Seriously, Dworkin mentions "the only three sorts of grounds that can consistently be used to limit the definition of a particular right." Government might show, for instance, that (1) the values encompassed by the original right are not really at stake, or that they are at stake in some attenuated form (DWORKIN, 1977, p. 200). It could also point out that (2) "if the right were so defined, then the cost to society would not be simply incremental, but would be of a degree far beyond the cost paid to grant the original right, a degree great enough to justify whatever assault on dignity or equality might be involved.”

According to Jürgen Habermas, even if it is reasonable to assert that human dignity usually prevails against other rights, such prevalence is not absolute. There are unavoidable situations in which it will be at least partially defeated (HABERMAS, 2010 , p. 464, 466 and 470). ${ }^{3}$

The question that arises here is how should a judge or the Government decide between competing claims of right? How to determine if something is, or not, an exception to a given trump? As I will try to show, the answer to this question gives us a reason for which trumping and balancing are compatible.

The notion of fundamental rights as trumps indicates that such rights are not totally at the disposal of the ordinary legislator. This makes sense in countries like France, Germany, Portugal, Spain or the USA, where the Constitution is a formal and solemn document that is placed above all other norms or statutes, and can be amended only through a complex legislative procedure.

On the other hand, how can one find out what is not at the disposal of the ordinary legislator? What is so important as to trump most of a society's welfare, aggregative and utilitarian interests?

Even if we accept that such fundamental rights exist and that some legal entitlements are so important as to trump most collective considerations, we still haven't said what those rights are and what their exceptions are.

\section{What does balancing MEAN AFter All?}

Some believe that proportionality is the most adequate tool for assessing whether a given limitation of a constitutional right is or is not lawful. Proportionality involves three steps, the first two being suitability and necessity. Explaining the first two is beyond the scope of this text, but it is relevant to mention that most limitations to a fundamental right will pass the first two steps. In most cases, it all comes down to the third (SIECKMANN, 2009, p. 47 f.).

Balancing is the third step of proportionality. It is also called proportionality stricto sensu. Balancing involves three steps. First, the degree to which a given right is 
infringed must be assessed. Second, the importance of satisfying a competing principle is established. Finally, it must be decided whether or not the importance of fulfilling the competing principle justifies infringement of the right involved (KLATT; MEISTER, 2012a, p. 10 and 57).

In such terms, it is evident that balancing imposes on public authorities a burden of justification which obliges them to defend a limitation to a constitutional right in terms of public reason. In other words, it provides a structure for the assessment of public reasons (KUMM, 2010, p. 150).

One of the arguments constantly made against balancing is that it offers no mathematical or algorithmical process of adjudicating on constitutional or human rights. This is indeed the case, but it is hard to see why it should be taken as a criticism of balancing. Grégoire C. N. Webber, for example, criticizes balancing for purporting to evade "political and moral questions", as if decisions on constitutional rights could be made merely a matter of weighing the relevant interests (WEBBER, 2009, p. 105). He also states that it fails to provide a categorical answer (ibidem, p. $110 \mathrm{f}$.), deconstitutionalizes rights (ibidem, p. $100 \mathrm{f}$.), and makes them "lose any sense of certainty" (ibidem, p. 103). A rebuttal of this thesis lies beyond the appropriate scope of this article. However, a few things should be said on the matter.

First, one can easily acknowledge that balancing does not involve "reasoning that is value-free, purely logical, and immune to any subjective influence and to any moral consideration" (SILVA, 2011, p. 288). In addition, as Virgílio Afonso da Silva has pointed out:

The faith that balancing as well as the principle of proportionality turn "the review process into a relatively straightforward exercise of logical or syllogistic reasoning" or that subjective points of view "never come into play", is a very naïve approach. (idem)

Yet such considerations do not in any way undermine balancing. To say that it does not entail mathematical precision ${ }^{4}$ (TSAKYRAKIS, 2009, p. 469, 472 and 474), something arguably impossible in legal reasoning, is not a meaningful critique. Of course, balancing does not yield mathematical or syllogistic accuracy, or even the pretense of one (ALEINIKOFF, 1987, p. 1003), but this lack does not prevent balancing from being useful and plausible.

Second, the lack of an indisputable and uniform measure (WEBBER, 2009, p. 89 f.) of logical deduction or mathematical precision does not render balancing irrational. This is so mainly because the major strengths of the doctrine of balancing, as epitomized by Matthias Jestaedt (2012, p. 157-158), are: (1) contributing to rationalization; (2) allocating burdens of argumentation; (3) providing justice and accuracy in the individual case; (4) consistently explaining constitutional case law. These four strengths 
are in no way related or subordinated to mathematical precision or to the adoption of a uniform measure. Moreover, as Virgílio Afonso da Silva has consistently demonstrated, two incommensurable values (i.e. those that cannot be reduced to a single measure or uniform scale) can be compared with one another. ${ }^{5}$

One can also object to balancing by questioning and undermining the legitimacy of judicial review in general. However, if such an approach is rejected, one must arguably accept that balancing is inevitable. It might be fallible and can lead to different results, but that does not mean it is not the most rational option available (SILVA, 2003, p. 87).

As Bernhard Schlink has put it, "[m]ost courts claim the right to control the balancing of the legislature and replace it by their own balancing [...] some courts feel this urge on more occasions than others" (SCHLINK, 2012, p. 300-301) ${ }^{6}$ But this argument forcibly challenges judicial review per se.

Even assuming, for instance, that a Constitutional Court should adopt a minimum core approach while adjudicating on constitutional rights, the objection remains. By advocating that Courts should limit their adjudication to the safeguard of a minimum regarding constitutional and human rights, it still means the opinion of the Court prevails over that of the majority. Indeed, it means the balancing of means and ends established by the legislator is superseded by that established by an unelected body of judges (SILVA, 2003, p. 85-86).

In other words, once judicial review is accepted, balancing is unavoidable, on a larger or smaller scale. I will try to show that the adoption of balancing in the adjudication of constitutional rights does not entail totally disregarding public interests when such rights come into play. However, nor does it require us to give up on the notion of rights as trumps.

\section{Making trumping and balancing compatible}

As I have tried to show in sections 1 and 2 of this article, Dworkin, who famously defended the idea of rights as trumps, does not claim that they are, as such, absolute. Trumps do admit exceptions, which makes them relative rights (KLATT; MEISTER, 2012a, p. 29).

If trumps admit exceptions and if I can show that balancing plausibly helps us undertake the difficult mission of finding out what those exceptions are, then the idea of rights as trumps and that of balancing are not only compatible, but also complementary. If I succeed at this task, not only can trumping and balancing be reconciled, but we will be better off if they are. That's precisely what I will try to show in the present section.

Fundamental rights set the bar higher: they impose burdens of argumentation and limit the discretion of the ordinary (i.e. non-constitutional or sub-constitutional) 
legislator. This means that some interests are valued to a certain extent regardless of the good or bad consequences that they may bring. They are, after all, intrinsically valued (SIECKMANN, 2009, p. 65). Therefore, once a society sets some rights as having a certain priority, it means they can be overridden only under special conditions.

If balancing were to put public interests and constitutional rights at exactly the same level, the state would be free to use any thinkable, and in part arbitrary, public interest to justify interference with such rights. That would truly undermine the ability of constitutional rights to assure any protection (KLATT; MEISTER, 2012b, p. 162-163).

The requirement that a higher weight be assigned to constitutional rights is based on the fundamental liberal idea that a certain priority be given to them over other ordinary interests. This is so, because "a heavier weighing of constitutional rights is intrinsic to the existence of a catalog of such rights" (KLATT; MEISTER, 2012b, p. 163-164).

If it be objected that this special status is not present in Alexy's Theory of Constitutional Rights, since collective and individual interests are placed at the same level there (ALEXY, 2002a, p. 80-81), the response must be that while this is true of Alexy's model, it is not true of every conceivable theory of constitutional rights that includes balancing as a method. In fact, in a theory of constitutional rights we can "assign higher abstract weights to some liberties considered more basic than other liberties" (KLATT; MEISTER, 2012a, p. 28). This means that some rights enter the balancing process with a "winning margin" (ibidem, p. 26). This possibility "would establish a lexical ordering among the principles, which is qua definition of the concept of abstract weights irrespective of any concrete case" (ibidem, 2012, p. 28).

Thus, "the idea of trumping or lexical ordering between principles can indeed be incorporated into the proportionality model by means of abstract weights" (KLATT; MEISTER, 2012a, p. 64). Under this view, the issue becomes "not whether trumping and balancing gives the correct account, but rather what is the proper place of trumping and lexical ordering within the balancing model" (ibidem, p. 28).

One must agree with Matthias Klatt (KLATT; MEISTER, 2012a, p. 28-29) that Afonso da Silva (2011, p. 286) is wrong when he states that balancing is always "made among concrete alternatives and not among abstract values". This could only be true by definition, but balancing does not require different principles to have the same abstract weight. Afonso da Silva believes that incommensurable values, including what he calls essential values (wesentlicheWerte), are only comparable concretely. From this perspective no abstract weight given to conflicting values can be used in a comparison or, more importantly, in a balancing procedure (SILVA, 2003, p. 177).

Can "playing golf" and "life" be compared? What about "collecting insects" and "friendship"? Afonso da Silva says that, based on their abstract dimensions, the answer must be negative (ibidem, p. $179 \mathrm{f}$.). They are incommensurable values that are at the same time comparable, but only concretely, not abstractly. I concede this might be true about "playing golf" and "life", but I disagree that it is the case when a collision 
of constitutional rights is at stake. There is no reason why abstract weights cannot be attributed to constitutional rights or values. It is, indeed, possible to compare them abstractly. The so-called preferred position of free speech, in the view of Justices William O. Douglas and Hugo Black, would be an example of that. ${ }^{7}$

Neither justice thought free speech had precedence in all circumstances over any other fundamental right or value guaranteed by the bill of rights. They merely believed that the liberties of the First Amendment to the American Constitution, such as freedom of speech, had greater weight per se than other liberties, and that this should be taken into account when ruling on judicial disputes. In this regard, I see no epistemological problems in ascribing abstract weights to constitutional rights. I should also add that this need not involve an absolute lexical ordering, as Afonso da Silva seems enthymematically to assume (SILVA, 2003, p. 181-183).

All this means is that a constitutional or human right begins the balancing process with a winning margin. To illustrate, it is as if the trump weighs slightly heavier on one scale because it has a heavier abstract weight. The imaginary scales of judicial balancing already tilt to this side. Abstractly speaking, it begins thus, so that in order to make the scales favor the opposite side, the concrete weight of the competing principle must be heavier than usual.

In other words, when two principles start with the same abstract weights or none, concrete balancing is done between equals. The scales truly balance. When a trump comes into play, this changes substantially: it enters the stage with an advantage, with a winning margin. In fact, by assigning abstract weights to rights, which means giving them a winning margin in the balancing process, we lay down "a proper way to combine proportionality and trumping” (KLATT; MEISTER, 2012a, p. 29) or, for that matter, trumping and balancing.

In his elucidating monograph on proportionality, which thoroughly addresses the relation between trumping and balancing, Matthias Klatt sets out two laws of trumping. According to the first one:

Constitutional rights always trump every consideration except for considerations which enjoy constitutional status likewise. (KLATT; MEISTER, 2012a, p. 23)

Furthermore, the second law of trumping states that:

The higher the abstract weight of a right, the more likely it will trump competing considerations. (ibidem, p. 29)

Both laws increase the burden of argumentation for whoever wants to confute a trump. The trump itself actually becomes strengthened, because it cannot be set aside 
without a good justification. No originalist, historical or genetic reason will, by itself, simply withdraw and remove a collision of a right with another constitutional interest from consideration by shrinking the right's scope. ${ }^{8}$

But it would be a mistake to claim that "exceptions" to trumps can be found without balancing. As we have seen, there is a need to create exceptions. The most rational way to do this is balancing. I will argue that Dworkin does accept that collective goods and consequentialist factors matter when establishing the exceptions to a given trump. Trumps are, indeed, defeasible. What must be found out is how and when.

Dworkin rejects the notion of a prima facie constitutional right. In accordance with his view, for instance, there can be no "prima facie constitutional right to medical care on demand that is however trumped by some emergency that prevents judges from actually enforcing it” (DWORKIN, 2011, p. 413). In an emergency, he says, it is the "very principles" (idem) that support such a right, "which include principles about the best allocation of political power in a coercive state, which supply the argument against enforcement” (idem).

How does he reach this conclusion? Is it by some kind of "constitutional vaticination or prophecy?"When one concedes that there are exceptions to trumps, then it is all the more rational and transparent to use balancing, instead of simply stating that an exception is inherent in the trump, or derived from it.

When Dworkin concedes that an emergency can exempt government from providing the medical care an individual is normally entitled to, he believes this is an obvious exception to the right to free health care, which he considers a fundamental right. He sees no conflict whatsoever between what should be done and the factual barriers that stop that duty from being accomplished. It is as if a constitutional right simply disappeared or ceased to exist in the event of an emergency. It is entirely beyond the right's scope. But what type of emergency justifies setting aside a fundamental right?

In principle, individuals have a right to undertake public religious demonstrations. One can take part, for example, in a religious or funeral procession. But what if the risk of an epidemic makes it unreasonable to allow a religious procession to go ahead under certain conditions of time and place? (ALEXY, 2002a, p. 208 f.)

Again, balancing offers a more rational and transparent method to answer this question. Simply saying that the exception is a necessary conclusion from the fundamental right itself, from its scope, does not help much. How do we define a right's scope? If we accept an internal theory, collisions between rights vanish only apparently, despite the fact that arguments used to reach a certain decision become less traceable. This means that there are situations in which matters of policy do interfere and neutralize a certain trump. In other words, trumps, which are matters of principle, to use Dworkin's terminology, are not totally immune to the weighing of consequences that is inherent in balancing. 
Under this approach, not every trump is an ace of trumps (i.e. insurmountable or insuperable). Depending on the concrete situation, every trump is capable of being overridden. This can only mean that what trumps do is raise the bar and elevate the stakes involved. They are burdens to those who wish to override them. Rights that are trumps deserve deference by definition and should not be so easily set aside on consequentialist grounds as other rights or interests. Nevertheless, they are defeasible.

I am not sure if, as Matthias Klatt argues, on "Rawls's or Dworkin's account" lexical ordering always and definitely means trumping principles with lower abstract weights (KLATT; MEISTER, 2012a, p. 28). That seems to be ambiguous at the very least, since, as I tried to show above, Dworkin accepts a number of exceptions to trumping that are somewhat vague and quite encompassing. Besides, I have argued that the only rational and transparent way to find exceptions is through balancing, which would mean that even Dworkin's account is at least compatible with balancing, if not in need of it. This objection also appears to apply, at least partially, to Rawls. ${ }^{9}$

When Dworkin accepts that the enforcement of a trump can be blocked if it entails a catastrophe, he takes consequences into account. Even though he rejects an aggregative justification for legal rights, in certain circumstances aggregative reasoning will play a role in the type of reasoning he defends. He wants to avoid catastrophe-based arguments, which can also be called high stakes objections, ${ }^{10}$ to his predominantly deontological account. But the exceptions to trumps he concedes can only be plausibly obtained through balancing. If no such rational process is used, absolutely no guarantee can be given that what he means to be exceptions will become the rule, in which case trumps will be too weak to trump anything. Balancing cannot give such a guarantee either, but it may help us get there.

If we want fundamental rights to rule out most consequentialist considerations, it is of paramount importance to submit legal argumentation to transparent and rational scrutiny. As far I can see, balancing provides the best way to achieve that. Balancing is not immune to all subjectivity. It does not guarantee specific results. In fact, different judges or lawyers may use the same method (i.e. balancing) and arrive at totally different conclusions. Nevertheless, it offers us a framework for discussions regarding constitutional or human rights that enhances transparency and distributes burdens of argumentation.

Although it is compatible with different levels of protection, balancing raises formal requirements for the content with which the structure is filled.

In addition, the above considerations show that fundamental, constitutional or human rights are better understood as "trumps subject to a general balancing clause" (direitos fundamentais como trunfos sujeitos a uma reserva geral imanente de ponderação) (NOVAIS, 2012, p. 80 f.). They are trumps, but not absolute ones. Their exceptions can be plausibly laid down through balancing. 
Notwithstanding what I have just said, it is crucial not to overstate my point: balancing does not eliminate subjectivity from legal reasoning. Far from it. What it does is establish a basic set of rules of argumentation and, most importantly, force the judge to argue more conspicuously. In other words, it enables trumps to institute burdens of argumentation, by making it harder if one wants not to give them precedence in a concrete legal case.

\section{TRUMPING AND PROMISING}

When Dworkin asks whether human rights are truly universal, i.e. whether human rights depend on features of local culture or history that universal declarations ignore, he answers: "yes and no" (DWORKIN, 2011, p. 338). For him, a "health education policy that would show good-faith effort in a poor country would show contempt in a rich one" (idem). Nevertheless, he insists that the abstract standard itself, the basic understanding that dignity requires equal concern for the fate of all and full respect for personal responsibility, is the foundation for government's duty to establish a health education policy, and as such is universal (idem).

Dworkin's thesis that human rights do depend on parochial reasons seems to proceed. Otherwise, we would have to accept that human rights will only be respected "until some millennium of wealth and cultural sophistication has been reached" (DWORKIN, 2011, p. 252). Strictly speaking, this means that the fulfillment of human rights shouldn't be measured sub specie aeternitatis.

This is relevant because it shows that the same right can be equally respected even though it is realized in different extents according to the given legal and factual possibilities. That's precisely what balancing is about (ALEXY, 2002a, p. 47).

To elucidate this, and to help showing that trumping and balancing are compatible and complementary, it is important to remember that Dworkin believes that the idea of rights as trumps should be understood as analogous to that of promise (DWORKIN, 2011, p. 329). Promising means, for instance, that if I borrow money from someone and promise to pay her, I can't simply argue later on that, instead of paying her - let's suppose she is single - I will travel with my wife and nine kids since from a purely utilitarian point of view that will make more people happier and arguably generate greater general utility. That wouldn't suffice to exempt me from my obligation.

In Justice for Hedgehogs, Dworkin interestingly shows how the notion of trumping helps to explain how promises and fundamental rights should be understood. Fundamental rights institute onerous burdens of argumentation in their favor. Consequently, they are indeed similar to promises. Promises rule out a whole range of excuses and exceptions that would normally be accepted in other circumstances. Fundamental rights also rule out and trump a number of arguments and interests that would normally have a greater impact if they weren't matched by a trump. 
Stephen Guest points out that the first articles published by Dworkin were interesting, among other things, for their display of an "anti-utilitarian strain" (GUEST, 2012, p. 12). Guest also indicates how easy it is to detect the "influence of Rawls's very influential article 'Two Concepts of Rules' published in 1955” (idem) on Dworkin's first texts. This is all the more important when one remembers that among the main ideas developed by Rawls in this article is the "question of promise" (RAWLS, 1955, p. 29).

Rawls believes that "utilitarianism cannot properly account for the obligation to keep promises at all" (ibidem, p. 33) It is fair to say the "question of promise" remained one of Dworkin's main concerns until the last book he published while alive (DWORKIN, 2011, p. 308 f.).

However, although promises do act as trumps, Dworkin explicitly acknowledges that promises are not immune to all exceptions. A promise to go out to dine, in his view, "could not have raised the bar so high that, for instance, your son's illness would not excuse you. None of these near platitudes offers an algorithm for testing promises and their breach. We can only say that we must assign a high level of seriousness to promises - but not too high - when we draw our judgments about promise-keeping from, and integrate them with, our other and more general convictions about not harming people” (DWORKIN, 2011, p. 311)

But how should we select the arguments that are good grounds for not keeping a promise, if, as Dworkin acknowledges, there is no Archimedean perspective or algorithm for that? If one is looking for transparent and rational grounds, balancing seems to be a sound answer. And if there seem to be cases in which no exceptions to a given promise or fundamental right exist, these can also be captured by a balancing process. Rights that admit of no exceptions whatsoever are classified as absolute. In other words, a right is "absolute when it cannot be overridden in any circumstances, so that it can never be justifiably infringed and it must be fulfilled without any exceptions" (GEWIRTH, 1981, p. 2) Relative rights, on the other hand, can be "lawfully interfered with in pursuit of the protection" of other interests, which means that "certain considerations can operate to override the right" and that "not all restrictions [...] amount to violations" (MAVRONICOLA, 2012, p. 730).

In explaining the apparent existence of absolute rights, Alexy states the following:

There are thus conditions under which one can say with a very high degree of certainty that no countervailing principle will take priority. These conditions define the "essential core of private life". But the absoluteness of its protection remains a matter of the relation of different principles. A set of circumstances under which competing principles do take precedence after all cannot be ruled out. However, the certainty of protection is so high that under ordinary circumstances we talk about absolute protection. But the relativized basis of this protection must not be lost from sight. The 
extent of "absolute" protection depends on the balance of principles. The impression that the core can be identified directly without balancing interests, or known intuitively, derives from the certainty with which we are able to relate principles in the case. (ALEXY, 2002a, p. 195-196)

The relative certainty that a certain right will give way to no other right in ordinary circumstances can also be explained through the balancing framework. This is also a reason why trumping and balancing are compatible.

Most political questions are and should be "a version of a utilitarian trade-off argument” (DWORKIN, 2011, p. 329). Trumps are different. They are the very rights that are normally immune to such a "utilitarian trade-off". They trump almost all the various justifications concerning "the general welfare or any other all-thingsconsidered justification" (ibidem, p. 330) However, Dworkin agrees that this cannot mean that such trumps admit no exceptions (ibidem, p. 310-311). They undoubtedly have to.

The question, of course, is which exceptions. If promises, for instance, are like trumps, as Dworkin argues, that can only mean that promises, like trumps, "set the bar very high for successful excuses for disappointing deliberately encouraged expectations. A promise makes a whole range of excuses ineligible that would be sufficient if reliance had been encouraged in some other and less heightened way" DWORKIN, 2011, p. 310) Again, there is a parallel with the idea of a fundamental right, which, as we saw, means that Government is not "justified in overriding" it "on the minimal grounds that would be sufficient if no such right existed" (ibidem, p. 192).

Joseph Raz sustains the view that promises are exclusionary reasons, and, as such, content-independent reasons to act. ${ }^{11}$ I should make clear that Raz develops this idea very differently. His writings on promises adopt a different approach from mine and have very distinct purposes. At any rate, he admits that promissory reasons (i.e. reasons that valid promises constitute for performing the promised act) have exceptions. ${ }^{12}$ Consequently, he says, it is relevant to understand the "distinction between binding promises that are overridden by conflicting reasons, and promises that are not binding".

Promises, like other trumps, can only be content-independent to a certain extent. They do not exclude any grounds to act; they exclude some grounds to act. The scope of the exclusionary force of a trump is limited. This applies with all the more reason to constitutional rights, which also have exceptions. Finding these exceptions is a matter of argument, through the assessment of competing claims and priorities.

Unfortunately, it is not reasonable - and perhaps not even possible - to list exhaustively all the possible collisions of constitutional rights or values, such as cases involving freedom of conscience and religion and freedom of speech, to mention only one possible example. Thus, finding what is in fact trumped by a trump is not so easy. 
The most plausible thing to do seems to be to institute argumentative burdens to any claim against the trump. I will turn to this question again in section 9 . In any case, denying the trump a limited scope favors the protection of constitutional rights. It is not only relevant what limitations of a right amount to a violation of it. It is also of paramount importance that any conduct potentially capable of infringing that right be submitted to constitutional scrutiny.

That is why, when it comes to constitutional and human rights, the difference between the so-called internal and external theories becomes so relevant.

\section{INTERNAL THEORY V. EXTERNAL THEORY}

Both Dworkin and Alexy admit exceptions to any fundamental rights, regardless of the fact that they are trumps. The difference lies in how they do so. Dworkin insists that all exceptions are, and must be, inherent in the trump in question (internal theory) (DWORKIN, 2011, p. 413). Alexy, however, is forced to exhibit conspicuous and compelling reasons to put aside a prima facie right (ALEXY, 2002a, p. 179 f.).

The internal theory dodges and conceals the fact that there is a tension between conflicting interests or colliding rights in every decision that trumps a trump. ${ }^{13}$ The internal theorist will try to show that there is only an apparent conflict or collision, and that the exception he defends is in fact a case of non-applicability, from the outset, of the trump in question. It is as if the trump and what is guaranteed by it had never been called into question. This means that "the right's content and the considerations for the right's restrictions are mixed up" (KLATT; MEISTER, 2012a, p. 21).

While Dworkin believes that fundamental rights trump most utilitarian considerations, he concedes that the occurrence of catastrophes and other similar incidents can be, for him, plausible excuses against a trump. For him, if a promise can be violated in certain circumstances, it is not because of some balancing process in which two competing interests are balanced. It is simply internal to the idea of a promise that it shouldn't be kept in certain circumstances. Promises are not binding come what may.

As a matter of fact, they are no exceptions at all to a given right, since its supposed limits are built in to the very scope of the right. In this context, Alexy's thesis can be classified as an external theory, since it claims that there is a prima facie right, which can be subject to limitations and exceptions. The external theory is generally connected to the idea that constitutional rights have a wide scope, so that a general right to liberty can be limited on certain grounds, while the internal theory is usually associated with a narrow scope (ALEXY, 2002a, p. 200 f.). ${ }^{14}$

The idea of a broad prima facie right to freedom, defended by Alexy, is similar to Isaiah Berlin's concept of negative liberty (BERLIN, 2002, p. 169-178; PULIDO, 2007, p. 472-475). From this standpoint Alexy's theory has an important liberal component, 
which is substantially different from Dworkin's. Alexy presupposes, in liberal fashion (BOROWSKI, 2007, p. 47 f.), that individuals have at least a prima facie right to do whatever they want, ${ }^{15}$ even if such liberty can be restricted. Dworkin clearly refuses the idea that any general account of negative liberty, even prima facie, can be plausible, and explicitly criticizes Berlin's approach (DWORKIN, 2011, p. 367 f.; 1977, p. 267).

From a certain perspective, the internal theory should present no more challenges than the external theory. For instance, one can always dispute what rights should be trumps and how much the scope of such trumps should cover; but mutatis mutandis that is also true of the external theory, in which case people can always argue about what the admissible limitations of the prima facie scope of a right should be.

However, the external theory forces those who deliberate to acknowledge the fact that their decision is by no means obvious. They are, indeed, weighing conflicting interests and the external theory makes that clearer and more traceable. It is possible to arrive at precisely the same results from these two different theories, but that does not suffice.

The internal theorist tries to evade the incidence of the trump from the outset. From a certain point of view, which Jorge Reis Novais has somewhat misleadingly called "theoretical", the internal theory can be considered irreproachable. In spite of failing to provide a rational and transparent way of controlling the (un)constitutionality of limits imposed on a certain fundamental right - precisely because it blends the right's content and limits -, the internal theory supplies a very rigid, "aprioristic" or ultrarestrictive delimitation of fundamental rights that conceptually eliminates conflicts between rights (NOVAIS, 2012, p. 32). Nevertheless, the practical problem remains: Where does the scope of a right end? How can I find that out? In the internal theory this question is answered from a conceptual point of view, regarding the very definition of the right. In the external theory, the conflict is left unobscured and unclosed, only to be solved by balancing. The methodological difference between a right's scope and its limits favors the traceability of decisions made by a given Court.

Moreover, the internal theory may give the impression that all the rights and interests secured by a given legal system are in perfect harmony, since there must be no overlap whatsoever between the scopes of any rights or trumps. That makes it all look simple, precisely because it is holistic. After all, in the internal theory, "[...] the scope of constitutional rights is determined as per their interpretation" (BARAK, 2012a, p. 493) Therefore, limitations "are a part of the constitutional rights. They do not limit it. Rather, they determine its content in accordance with the community's view at a given time" (idem).

However, it seems far more preferable to have "a model that stresses, in the most transparent way possible, the conflicts of interests, values and principles that underlie 
all the hard cases that involve fundamental rights" (NOVAIS, 2012, p. 31). The adoption of such a process, according to Reis Novais (idem), means that, while solving such conflicts, one is able to control the given solution in an "intersubjectively shared" manner, instead of "semantically obscuring" or "theoretically neutralizing" the types of conflicts between fundamental rights that frequently underlie a concrete constitutional case.

One of the results of Dworkin's internal theory is that equality and liberty, for instance, never overlap and are never in an area of conflict (DWORKIN, 2000, p. 121, p. 134; 2006, p. 69-70). They do not collide at all. If we accept the internal theory, we are also obliged to concede, for example, that there is simply no opposition or tension between majority rule and fundamental rights, a view Dworkin also shares (DWORKIN, 2011, p. 382 f.). ${ }^{16}$

As one can easily see, it is no coincidence that in Justice for Hedgehogs Dworkin painstakingly defends the two views I just mentioned, namely that equality and liberty or majority rule and fundamental rights never collide with one another (DWORKIN, 2011 , p. 345 f.). It is as if when equality is applicable, liberty leaves the stage and the other way around. Concepts are shaped in a holistic view, which means Dworkin defends a very specific, narrow and exquisite view of equality or liberty.

That is also why Dworkin criticizes the well-known dichotomy, advanced by Benjamin Constant (1997, p. 589-619) and resumed by Isaiah Berlin (2002, p. 166 f.), between the liberty of the ancients and the liberty of the moderns. As an article by Kathleen M. Sullivan shows, the distinction between the two concepts of freedom has become very important in the understanding of constitutional rights, such as freedom of speech. ${ }^{17}$ Nevertheless, according to Dworkin there is no contrariness between political participation and the right to choose as part of a group (liberty of the ancients) and the guarantee of an inviolable sphere of individual liberties (liberty of the moderns).

Moreover, so the argument goes, there is no value in liberty for its own sake. For Dworkin, the only liberty we should not be deprived of by Government is the one that is essential to our dignity (DWORKIN, 2011, p. 345). If individuals are deprived of a single individual right, they are seriously wronged. But if a single unwarranted individual right is granted to a citizen that is already too much. Hence, the argument assumes there is a very neat division between what is a matter of principle, and what is a matter of policy. If affairs that should be decided in consonance with collective goals are decided differently, society is deprived of its democratic prerogative of selfdetermination. Similarly, an individual is severely wronged if a choice he should be able to make by himself is made by society as a whole.

Accordingly, Dworkin famously differentiates between freedom and liberty. Freedom is the complete power to do what one wishes, while liberty is only that part of freedom which, if constrained, would engender a violation of my dignity. From this 
perspective, not all opposition to my will is an opposition to my liberty, because I am simply not entitled to do anything I want (DWORKIN, 2011, p. 366 f.). I do not have the right to commit theft ${ }^{18}$ or murder, for example, which means the Government can do me no wrong by prohibiting me from doing so (ibidem, p. 369). The internal theory neutralizes the collision between different constitutional or human rights, since it "seeks to provide every right with a clear and well-defined scope such that it would not conflict with other constitutional rights” (BARAK, 2012a, p. 514).

But there is an evident moral and liberal objection that can be made about simply singling out some acts and putting them outside of the right's scope. Kai Möller mentions the case of a hitman who argues that killing is very important for him. It is part of his conception of a good life and of the person he wants to be right now and in the future (MÖLLER, 2012, p. 72, fn 58).

The dispute here is not about whether murder and theft should be prohibited. Of course they should. The point here is that someone's project is a result of the free development of his or her personality. Autonomy means precisely being able to do things that might be worthless for other individuals or for society in general simply because the individual wants to. When assessing the scope of a right, neutrality should be a key feature. The moral value of a certain conduct is to be assessed when judging if there is sufficient justification to limit that right, but the state cannot be completely exempted and discharged from justifying the limits it imposes on the autonomy of individuals (MÖLLER, 2012, p. 77-79).

Another objection that arises instantly against the internal theory is that the reduction of the de facto conflict between two or more constitutional rights or the interests they involve "leads to an interpretative result that leaves some aspects of the right's penumbra outside its recognized scope” (BARAK, 2012a, p. 514).

Dworkin's idea arguably works well in cases that are plain or obvious, such as theft or murder, but offers little or no help at all in minimally disputed cases. This makes it a very unpersuasive and unworkable theory, since "a legal theory that does not help, or does not help much in cases of doubt, is not much use" (ALEXY, 2002a, p. 214).

Suppose I had promised to go to the theater with a friend. As I was on my way to meet my friend, I found a stranger lying on the street in a pool of blood. The example may seem a bit dramatic, and perhaps unreal, but it does not necessarily have to be. It is helpful because it offers quite a solid case for a promise to be reasonably broken. I find it quite sensible to break a promise to go to the theater in order possibly to save someone's life. This conclusion could be reached by both the internal and the external theorist. But how exactly?

The main point here is that, in keeping with the internal theory, there is no point in saying that I feel or at least should feel divided between keeping a promise and helping an injured stranger who has just been shot. Thus it is not about weighing the arguments and counter-arguments for and against helping the stranger. I reach that conclusion by 
simply acknowledging that in such circumstances I never had a duty to obey the promise I made. In other words, the trump established by a promise was never meant to apply if I found a stranger lying on the street minutes before accomplishing what I had promised.

The external theorist, on the contrary, would say the promise is still binding but, given the overwhelming situation, there is more than enough reason to put it aside and help the injured stranger. The external theorist recognizes the prima facie duty he has and puts the bar really high before he is allowed to surpass it. In addition, the external theorist actually enhances the relevance of the trump, because he denies that it is simply non-applicable to certain cases. He is forced to give considerable reasons before putting the trump aside, no matter how trivial and apparently obvious those circumstances are or may be.

The internal theorist does indeed balance and weigh the different interests involved. Otherwise how would he decide if a promise must or must not be kept, or if a trump is really definite or not. Nevertheless, the internal theorist solves this collision "in a hidden way" (KLATT; MEISTER, 2012a, p. 21), which is "no longer traceable" (idem). In short, the internal theory is hopelessly and irredeemably stricken by a justification deficiency.

\section{DWORKIN, LAW AS INTEGRITY AND HOLISM}

Another shortcoming of Dworkin's theory, closely related to trumping and balancing, is that it is too holistic. In his words, "[y]ou cannot determine what liberty requires without also deciding what distribution of property and opportunity shows equal concern for all” (DWORKIN, 2011, p. 4). This suggests it is impossible to have a view on liberty without assessing all the concrete problems that might arise from the enforcement of that concept. If this were the case, we would be forced to have a complete and gapless theory of law and of the applicable legal system in order to reach a plausible conclusion in any given case.

It follows from this view that before I can actually know what freedom of expression is and before I can adjudicate on that basis I must know from the outset precisely what the following concepts mean, among many others: liberty, human dignity, procedural and substantive due process of law, equal protection of the laws, the right to property, the separation of powers, freedom of assembly, religious freedom, the right to petition, the right to keep and bear arms, and so on. I would need to have an answer to every single case that might arise, as well as a clear definition of all constitutional rights, before solving any dispute.

None of these rights I mentioned could possibly conflict with each other in Dworkin's account. Therefore I would have to know precisely what all their scopes were beforehand. Only under that condition would there be no overlap between the 
different scopes. In fact, there is no reason why I would not also have to know the scope of every other conceivable legal - and not only constitutional - right, entitlement and concept. ${ }^{19}$

One would have to know the scope of absolutely all constitutional rights to decide a case involving, in principle, only one or two constitutional rights. This holistic view, closely attached to Dworkin's idea of law as integrity (DWORKIN, 1986, p. 176-275), requires the judge to review at least virtually all the rights and values with or without constitutional status before arriving at any decision. It truly requires the labors of a demigod, such as Hercules, because it presupposes a kind of omniscience that is humanly unattainable. ${ }^{20}$ Besides, legal systems are in many ways incomplete and laconic. The solutions of many problems are engendered; they are not pre-existent.

It seems that not only is such a review of the complete legal system unlikely and really hard, if not unviable, but it also hides most of the judge's considerations before reaching a certain decision. Such a review not only has at least a tendency to continue ad infinitum, but also conceals, from an argumentative point of view, the contentious and mostly controversial questions concerning the delimitation of the scope of the constitutional right.

We should not assume that constitutional rights are clear and neat concepts, that freedom of speech and the right to privacy, for instance, never collide. As Justice Souter of the American Supreme Court once put it, "[t]he explicit terms of the Constitution [...] can create a conflict of approved values, and the explicit terms of the Constitution do not resolve that conflict when it arises" (SOUTER, 2010, p. 433). Consequently, a "choice may have to be made, not because language is vague but because the Constitution embodies the desire of the American people, like most people, to have things both ways. We want order and security, and we want liberty. And we want not only liberty but equality as well. These paired desires of ours can clash, and when they do a court is forced to choose between them, between one constitutional good and another one" (idem).

One cannot reasonably doubt that the Constitution does not have all the answers. Collisions of constitutional rights are unavoidable, given the provisions of most constitutional texts in the world. Likewise, Constitutions do not and could not have an exhaustive catalog containing the solutions to all possible cases that arise from the collision of constitutional rights (ALEXY, 2002a, p. 212). Furthermore, an absolute lexical priority between constitutional rights is also implausible. That would violate the unity of the constitutional text and, most importantly, the fact that all constitutional provisions possess the same hierarchy. In most legal systems, one cannot say that some constitutional rights trump all other constitutional rights and values. ${ }^{21}$

Nevertheless, the fact that the external theory stresses what is at stake and makes the decision process more transparent and accountable renders it preferable to the internal theory. Both would be equally plausible if we took only the outcome into 
account. But if we assume that judges act in good faith, the external theory imposes more burdens of argumentation.

\section{MAKING TRUMPING AND BALANCING COMPATIBLE II}

At its core, my argument is similar to Denise Meyerson's. She has argued against the "assumption that rights are merely one factor to be balanced at the first-order level against other factors" (MEYERSON, 2007, p. 882). She adds that "[w]hen reasoning on the balance of reasons, decision-makers assign all reasons the weight which they think they actually deserve" (idem).

However, she goes on, when it comes to constitutional rights one should adopt a weighted balance of reasons, which means that "some first-order reasons are artificially assigned a different weight from the weight they would ordinarily receive" (ibidem, p. 883).

As shown in section 5, assigning a "winning margin" for trumps when they are called into question is an adequate way of adopting Meyerson's proposal of "a weighted balance of reasons" (idem). As she notes, this model implies acknowledging that trumps are to a certain extent "exclusionary reasons", for they "instruct judges not to exercise their own judgment as to what the balance of reasons requires, but rather to assign a greater weight to rights and a lesser weight to the public interest than they would ordinarily think they deserve" (idem).

Such an approach has the valuable advantage of recognizing that "bills of rights do not exclude consideration of the public interest", while it also builds "into rights adjudication a 'systematic bias' against permitting the infringement of rights" (idem). This is all the more relevant if we accept that democratic discretion should not be "squeezed" into a tight spot, in such a way that only a single right answer is constitutionally admissible (ALEXY, 2002b, p. 216; MÖLLER, 2012, p. 118). Balancing can, for example, incorporate the idea of the Constitution as a framework (BÖCKENFÖRDE, 1990; ALEXY, 2002a, p. 390 f.), which means that constitutional rights establish a prohibition of insufficient means and a prohibition of excessive means (ISENSEE, 2000, p. 218 f., p. 231 f.; KLATT; MEISTER, 2012 a, p. 75 f., p. 85 f., p. 108; KLATT, 2011); thus balancing institutes the outer boundaries of state action. Anything inside the framework is a matter to be decided according to the legislator's margin of appreciation or discretion, while anything outside it, be it too much (excessive) or too little (insufficient), is considered unconstitutional.

This perspective provides a way of understanding constitutional or human rights as trumps. Thus it elucidates the conceptual similarity of constitutional rights and promises, which I briefly examined in section 6 . The resemblance resides in the fact that both constitute exclusionary reasons. Nonetheless, such exclusionary reasons do not override any other reason, but only some. 
I have tried to show that the best way to understand this feature of trumps is to incorporate balancing, in such a way that trumps have a greater abstract weight than ordinary public interests. I therefore agree with Aharon Barak, when he says that "the component of proportionality stricto sensu [balancing] may well incorporate the notions of 'rights as trumps', or 'rights as firewalls'” (BARAK, 2012a, p. 490).

It is noteworthy that if abstract weights are adopted in balancing, as Matthias Klatt has proposed and I have endorsed, Meyerson's distinction between first-order and second-order levels becomes superfluous. The intended result - ascribing less importance to the public interest - is reached with a simpler method. Balancing can also operate in a way that gives greater weight to trumps and non-consequentialist $^{22}$ concerns.

In light of the preceding considerations, Dworkin's account fails to perceive that balancing is not only about calculating the increase in general utility caused by a certain act. In most cases, that's not what it is about. When it comes to fundamental rights, it is mostly about weighing what constitutional interests or arguments can be so compelling and overwhelming that they are capable of overriding a trump. That does not have to be associated with a utilitarian background. General utility is not the only thing to be balanced. But in many cases, as I have tried to show, even Dworkin accepts that it does play a role when a trump is in question.

Hiding the existence of a collision will only hide the balancing that has taken place. Balancing can be useful to structure some general rules about what is required to put a trump aside. It is a rational and argumentative method used to weigh arguments and counter-arguments, as well as assessing the relation of means and ends involved.

As Matthias Klatt and Moritz Meister have put it,

Only the balancing model forces the judge to put her cards on the table and state clearly whether she thinks the one or the other [interference in a constitutional or human right] to be light, moderate, or serious, and, more importantly, what the grounds for these evaluations are. (KLATT;

MEISTER, 2012a, p. 65-66)

Balancing becomes all the more important, when we realize that the so-called external theory can enhance the transparency and rationality of a decision (KAHL, 2004). It can contribute to the accountability of a judge who sees herself forced to list the compelling and overwhelming grounds that lead her to set a trump aside.

If an internal theory is adopted, we have sound reasons to think that judges will continue to create exceptions to trumps, for this is unavoidable; however, through the delimitation of a given right's scope, they will have to find opaque, non-transparent and sometimes surreptitious ways to do so. That's the only option left if trumps are considered insurmountable. 
On the other hand, if one accepts that trumps admit exceptions, it would be quite beneficial if we could come up with a legal and argumentative framework that helps us make clearer the grounds of the decisions that acknowledge such exceptions. That's exactly what balancing offers us. Balancing per se does not make trumps weaker or more confusing. It establishes some clearer criteria while assessing what are the exceptions to a given trump. When rights are trumps, their limitations must be brought under heavy scrutiny. Balancing provides a framework for that.

\section{DOeS BALANCING SUFFICIENTLY SAFEgUARD CONSTITUTIONAL Rights?}

Moshe Cohen-Eliya and Iddo Porat have emphasized that proportionality carries to this day a pro-rights connection in Germany, where it is associated with a "culture of justification", while the opposite is the case for balancing in the United States, where a "culture of authority" allegedly prevails. In addition, they argue that European legal and political culture has shaped proportionality as intrinsic to the Rechtsstaat, to Government's accountability and to the realization of shared values, while in the United States a suspicion-based legal and political culture has shaped balancing in more pragmatic and instrumental terms (COHEN-ELIYA; PORAT, 2013, p. 24 f., p. 44 f, p. 111 f.).

I concede that such a legal-sociological analysis may be right, but that is because balancing allows for different levels of protection. It can indeed be used to strengthen or to weaken constitutional rights, in the sense of admitting more or less exceptions to them. What balancing does in any case is enhance the burden of argumentation, making the decision-making process more transparent. It does not guarantee results, one way or the other. Thus it is no more than a structure or framework, mostly devoid of content.

But organizing the input of argumentation and arranging the "external arguments", namely those that justify or confute the valid limitation of a constitutional right, are two great advantages supplied by balancing. Balancing does not produce ipso facto a more solid protection of constitutional or human rights. But if used wisely it can become a very important instrument to achieve such an important goal. In fact, it is the most reasonable tool devised until now to reach that target.

If balancing allows for different levels of protection, the question one should ask is this: How much protection do we want constitutional rights to provide? I believe the whole point of having them is to set the bar higher, making it harder for Government to override some basic entitlements on pretext of promoting public or collective interests.

If that is right, we should give constitutional rights a "winning margin" when public interests are at stake. We should assume that they have a certain priority, which can be overridden only in special circumstances. Otherwise, there would be no point in having such rights in the first place. 
Constitutional rights consist in a pre-commitment to certain values that put aside trade-off arguments, which are generally accepted in other circumstances. But trumps are not reason enough to exclude grounds of public interest come what may. Thus no trump is an ace of trumps (i.e. insurmountable or insuperable). Trumps are subject to emergencies, or whatever exceptions reason imposes. Balancing is the most proper way to find what those exceptions are.

Balancing structures the argumentative process. It does not solve moral problems; it does not supply one or more right answers. The moral or legal correctness of the result obtained through balancing depends on the weight assigned to the conflicting interests. Hence balancing provides no explanation of how much weight should be given to freedom of expression or to the right to privacy. It offers no more than a structure that will give a right conclusion (output), if the chosen premises (input) are correct.

And how should we assign weights to constitutional rights or values? Just as we do everything in law: through argumentation. Adopting proportionality or, more importantly, balancing, will not make it less controversial or disputed. One will have to assemble arguments that show, for example, that freedom of speech is essential to democracy or to respect for personal autonomy, and so on, and that such specificities constitute a reason to assign these a certain weight.

In many respects, balancing is like logic. In logic we study valid arguments, namely the passage through logical inference from certain premises to a conclusion. Mutatis mutandis, that is true of classical and non-classical logic. An argument is valid if the truth of the premises suffices to guarantee the truth of the conclusion. The whole point is to establish a connection between premises and conclusion, salva veritate - however changing the concept of truth might be. Nevertheless, there are many possible valid arguments that are incorrect and unsound. Here is a trivial example:

(1) All Chinese are French.

(2) All French are Brazilians.

(3) All Chinese are Brazilians.

This argument illustrates what seems to happen with both logic and balancing. Premises (1) and (2) are false, but we do not obtain such knowledge from our studies of logic. The truth of the premises is not a concern of logical reasoning; the relationship of the premises to the conclusion is. In fact, if (1) and (2) were true, three would forcibly be true. The validity of the argument is different from its correctness or soundness. Something similar happens in the case of balancing constitutional rights. 
In order to say if the outcome of balancing two rights is correct, I must rely ultimately on the weight assigned to the competing constitutional rights or values, as well as to the interferences with such rights or values. Every proof of proportionality presupposes moral argumentation, and it can only bring correct results if the moral or legal premises are sound (KLATT; MEISTER, 2012b, p. 170). Hence I must scrutinize the truth of the premises, since balancing is nothing more than a framework. In itself it is rational, in a similar way to logical reasoning. However, it does not follow that it is infallible, obvious though this might seem, if we take infallible to mean that the outcomes of balancing are always correct.

On the merits, the plausibility of the outcome of proportionality does not depend on balancing per se; it depends on the arguments that justify the weight assigned to the competing interests in question. This can only mean that, although balancing offers "an answer that cogently derives from accepted premises", it "is pointless to argue that balancing is problematic because it is possible that one person evaluates an interference as light while another evaluates the same interference as moderate. Disagreement is ubiquitous in legal argumentation and it would make no sense whatsoever to expect that balancing or proportionality could make it disappear" (SILVA, 2011, p. 291-292).

It follows that the fact that wrong premises lead to wrong conclusions and that balancing does not produce algorithmical answers to constitutional disputes are not sound criticisms. They are to be rejected.

\section{CONCLUSION}

It has been shown that it is possible to reach exactly the same conclusions regarding a certain fundamental right by starting from Dworkin's or Alexy's point of view. Both can agree upon precisely the same exceptions to keeping a promise, or defend exactly the same content for freedom of expression or due process of law etc. The main difference lies in the argumentation process through which they arrive at such conclusions.

Trumps have exceptions. No constitutional or human right is absolute; no trump is an ace of trumps (i.e. insurmountable or insuperable). I have tried to show that in order to find out what those exceptions are it is more plausible to adopt both balancing and the external theory. Particularly in cases that are harder to decide, where the question about the scope of a right or about its admissible limitations might not be so clear, it is much better from an argumentative point of view to adopt the external theory.

Dworkin's theory of right is seriously flawed when it assumes that constitutional rights are - or could be - neat and clear concepts that never conflict or collide. It follows from Dworkin's approach that a gapless and complete theory of law would be needed to adjudicate upon a case involving, in principle, a single constitutional right. One would need to know the scope of all constitutional and non-constitutional rights 
from the outset, since they cannot overlap. The rejection of such a thesis leads us to acknowledge that there has to be a way to find what the exceptions of trumps are. Balancing is the answer; it offers us a transparent and rational way to enhance the burden of argumentation, so that it becomes harder to override a trump, and it requires that conflicts between constitutional values be left unobscured and publicly scrutinized.

In addition, constitutional rights are not to be weighed on exactly the same level as other constitutional interests. It is distinctive of their raison d'être that they have a greater weight than ordinary rights, interests or values. Constitutional rights are exclusionary reasons. Therefore, while they do not exclude all reasons to act, they exclude some reasons to act. That's precisely what promises and constitutional rights have in common: both are trumps, and, consequently, exclusionary reasons.

Since balancing allows for different levels of protection, it is more plausible to assign trumps a "winning margin" when they are to be balanced against other constitutional values. This approach assigns greater weight to rights, which does not mean that they cannot be overridden by any consideration based on the public interest. Thus the distinction between first-order and second-order levels becomes superfluous. The intended result - ascribing less importance to the public interest - is achieved with a simpler method.

Accordingly, there is "nothing in the methodology of proportionality which contradicts a liberal antiperfectionist or anticollectivist democratic tradition. Proportionality is a legal framework that must be filled with content. It allows for different levels of protection" (BARAK, 2012a, p. 489-490). ${ }^{23}$ Balancing is a logical procedure, in the sense that it establishes a relation of inference between the premises and the conclusion involved.

The truth of the premises will always depend on facts that are external to balancing. It is impossible to affirm if the outcome of balancing two rights is correct without first examining the accuracy of the weight assigned to the competing constitutional rights or values, as well as to the interferences with such rights or values. One must scrutinize the truth of the premises, since balancing is nothing more than a framework.

In itself it is rational, in a similar way to logical reasoning, but the soundness of the result relies ultimately on the weight assigned to the constitutional interests in question. Just as an argument can be valid but neither correct nor sound, balancing can be internally valid but externally unsound. It will be valid if the result is forcibly derived from the assumed premises, but it will only be sound if the premises are also true as a matter of fact. 


\section{NOTES}

* I would like to thank Matthias Klatt, Julian Rivers and Luís Duarte d'Almeida for their comments on an earlier version of this text. I am also grateful to Professor Marcelo Neves and Justice Gilmar Ferreira Mendes for their invaluable academic support.

1 See, among others, Robert Alexy (2002, p. 67-68, p. 80 f., p. 397 f.); Virgílio Afonso da Silva (2011, p. 282); Julian Rivers (2002, p. xviii). Afonso da Silva, for example, says that 'When deciding such cases by means of balancing rights, courts necessarily take into account the factual and legal possibilities of each concrete case, which means that the same two rights can be ranked in opposite ways in two different cases. Trumping or similar relations cannot play a role here' (2011, p. 282). He adds that 'whenever an argument based on a trumping relation comes into play, balancing or weighing leaves the stage' (ibidem, p. 282, fn 44).

2 I do not dispute that Dworkin's theory of rights changed considerably over the years. But I do believe that it maintained some basic ideas, and if I am right, this suffices for my analysis. A comprehensive analysis of Dworkin's theory of rights is beyond the scope of this text, but can be found in Paul Yowell (2001).

3 For another defense of this view, with examples from different parts of the world, see Luís Roberto Barroso (2012, p. 354).

4 On this criticism, see Virgílio Afonso da Silva (2011, p. 288, fn 77).

5 See Virgílio Afonso da Silva (2011).

6 For criticism of the idea of constitutional rights as optimization requirements in general, see Bernhard Schlink (1992).

7 See Murdock v. Pennsylvania, 319 U.S. 105 (1943); See also, on the doctrine of preferred freedoms, Martin Kriele, (2000, p. 109 f.).

8 On the failures of originalism in this regard, see David Strauss (2010, p. 16 f., p. 20 f., p. 27); J. Harvie Wilkinson (2012, p. 33 f., p. 49).

9 See, e.g., John Rawls (1993, p. 295 f), where he makes his famous distinction between restriction and regulation of basic liberties, and asserts that the basic liberties and their priority are 'not required under all conditions'.

10 See Derek Parfit (2011, p. 331 f.).

11 See Joseph Raz, available at SSRN: <http://ssrn.com/abstract=2162656> or <http://dx.doi.org/10.2139/ ssrn.2162656> (October 16, 2012); See also Joseph Raz (1977, p. 210-228).

12 Joseph Raz, available at SSRN: <http://ssrn.com/abstract=2162656> or <http://dx.doi.org/10.2139/ ssrn.2162656 (October 16, 2012) p. 4-5.

13 For different versions of an internal theory of constitutional rights, see Friedrich Müller (1990, p. 18 f.); Jürgen Habermas, (1996, p. 254 f.); Klaus Günther (1992, p. 255 f., p. 309 f.).

14 The difference between a right's scope and its limitations, as well as the adoption of a dyadic or triadic theory to explain this phenomenon, is of such relevance to a theory of constitutional rights that it has become one of the central disputes in a recent debate between Robert Alexy and Jörn Ipsen. See Robert Alexy (2013, p. 87-98); Jörn Ipsen (2013, p. 266-293).

15 For a defense of the view that this would trivialize the very notion of constitutional right, see the dissenting opinion by Dieter Grimm in BVerfGE 80, 137 (Reiten im Walde).

16 For a recent contribution on the relevance of balancing to square the relation between formal principles derived from procedural and democratic decisions - and substantive principles - such as entitlements granted by 
constitutional rights -, see Martin Borowski (2013).

17 See Kathleen M. Sullivan (2010, p. 143-177).

18 For a rebuttal of this point of view, see Robert Alexy (2002, p. 215-217).

19 For a similar criticism, see Scott Shapiro (2011, p. 301 f.).

20 See, e.g., Enrique P. Haba (2001, p. 5-88).

21 For a rejection of balancing or weighing tout court in regard to the constitutional right against unreasonable seizures, see Maryland v King, 569 U.S (2013) (Scalia J., dissenting).

22 I use 'non-consequentialist' roughly in the same way as F. M. Kamm (2007, p. 1-47).

23 For a defense of this view from a slightly different perspective, see Aharon Barak (2012b, p. 750 f.).

\section{REFERENCES}

ALEINIKOFF, Alexander. Constitutional Law in the Age of Balancing. Yale Law Journal, n. 96, p. 943-1005, 1987. ALEXY, Robert. A Theory of Constitutional Rights Oxford: Oxford University Press, 2002a.

- Diskussionsbeitrag. VVDStRL, n. 61, p. 216-19, 2002b.

. Jörn Ipsens Konstruktion der Grundrechte. Der Staat, n. 52, p. 87-98, 2013.

BARAK, Aharon. Proportionality. In: ROSENFELD, Michel; SAJÓ, András (Eds.). The Oxford Handbook of Comparative Constitucional Law. Oxford: Oxford University Press, 2012b.

- Proportionality: Constitutional Rights and their Limitations. Cambridge: Cambridge University Press, 2012a.

BARROSO, Luís Roberto. Here, There, and Everywhere: Human Dignity in Contemporary Law and in the Transnational Discourse. Boston College International and Comparative Law Review, n. 35, p. 331-393, 2012. BERLIN, Isaiah. Two Concepts of Liberty. Liberty. Oxford: Oxford University Press, 2002.

BÖCKENFÖRDE, Ernst-Wolfgang. Grundrechte als Grundsatznormen: Zur gegenwärtigen Lage der Grundrechtsdogmatik. Der Staat, n. 29, p. 1-31, 1990.

BOROWSKI, Martin. Formelle Prinzipien und Gewitchtsformel. In: KLATT, Matthias (Ed.). Prinzipientheorie und Theorie der Abwägung. Mohr Siebeck: Tübingen, 2013, p. 151-199.

- Martin. Grundrechte als Prinzipien. $2^{\text {nd }}$ edn. Baden-Baden: Nomos, 2007.

COHEN-ELIYA, Moshe; PORAT, Iddo. Proportionality and Constitutional Culture. New York: Cambridge University Press, 2013.

CONSTANT, Benjamin. De la liberté des anciens comparée à celle des modernes (discours prononcé à l'Athénée Royal de Paris en 1819). Écrits politiques. Paris: Gallimard, 1997.

DWORKIN, Ronald. Is Democracy Possible Here? Principles for a New Political Debate. Princeton: Princeton University Press, 2006.

—_. Justice for Hedgehogs. Cambridge: Harvard University Press, 2011.

Law's Empire. Cambridge: Harvard University Press, 1986.

Sovereign Virtue: The Theory and Practice of Equality. Cambridge: Harvard University Press, 2000.

Taking Rights Seriously. Cambridge: Harvard University Press, 1977.

GEWIRTH, Alan. Are There Any Absolute Rights? The Philosophical Quarterly, n. 31, p. 1-16, 1981.

GUEST, Stephen. Ronald Dworkin. $3^{\text {rd }}$ edn. Stanford: Stanford University Press, 2012.

GÜNTHER, Klaus Der Sinn für Angemessenheit. Frankfurt am Main: Suhrkamp, 1992.

HABA, Enrique P. Rehabilitación del no-saber en la actual Teoría del Derecho. El Bluff Dworkin. Doxa, n. 24, p. $5-88,2001$.

HABERMAS, Jürgen. Between Facts and Norms. Cambridge: Massachusetts Institute of Technology Press, 1996. 
The Concept of Human Dignity and the Realistic Utopia of Human Rights. Metaphilosophy, n. 41, p. 462-480, 2010.

IPSEN, Jörn. Grundzüge einer Grundrechtsdogmatik. Zugleich Erwiderung auf Robert Alexy, 'Jörn Ipsens Konstruktion der Grundrechte'. 52 Der Staat, p. 266-293, 2013.

ISENSEE, Josef. Das Grundrecht als Abwehrrecht und staatliche Schutzpflicht. In: ISENSEE, Josef; KIRCHHOF; Paul (Eds.). Handbuch des Staatsrechts. $2^{\text {nd }}$ edn. Heidelberg: C.F. Müller, 2000.

JESTAEDT, Matthias. The Doctrine of Balancing: Strengths and Weaknesses. In: KLATT, Matthias (Ed.). Institutionalized Reason: The Jurisprudence of Robert Alexy. Oxford: Oxford University Press, 2012. KAHL, Wolfgang. Vom weiten Schutzbereich zum engen Gewährleistungsgehalt. Der Staat, n. 43, p. 167-202, 2004. KAMM, F. M. Intricate Ethics: Rights, Responsibilities and Permissible Harm. New York: Oxford University Press, 2007.

KLATT, Matthias. Positive Obligations under the European Convention on Human Rights. Zeitschrift für ausländisches öffentliches Recht und Völkerrecht, n. 71, p. 691-718, 2011.

KLATT, Matthias; MEISTER, Moritz. The Constitutional Structure of Proportionality. Oxford: Oxford University Press, 2012a.

-.Verhältnismäßigkeit als universelles Verfassungsprinzip. Der Staat, n. 51, p. 159-188, 2012 b.

KRIELE, Martin. Grundrechte und demokratischer Gestaltungsspielraum. In: ISENSEE, Josef; KIRCHHOF, Paul (Eds.). Handbuch des Staatsrechts. $2^{\text {nd }}$ edn. Heidelberg: C.F. Müller, 2000.

KUMM, Mattias. The Idea of Socratic Contestation and the Right to Justification: The Point of Rights-Based Proportionality. Law and Ethics of Human Rights, n. 4, p. 141-157, 2010.

MAVRONICOLA, Natasa. What is an 'absolute right'? Deciphering Absoluteness in the Context of Article 3 of the European Convention on Human Rights. HRLR, n. 12, p. 723-758, 2012.

MEYERSON, Denise. Why Courts Should Not Balance Rights against the Public Interest. Melbourne University Law Review, n. 31, p. 801-830, 2007.

MÖLLER, Kai. The Global Model of Constitutional Rights. Oxford: Oxford University Press, 2012.

MÜLLER, Friedrich. Die Positivität der Grundrechte. $2^{\text {nd }}$ edn. Berlin: Duncker \& Humblot, 1990.

NOVAIS, Jorge Reis. Direitos fundamentais e justiça constitucional em estado de direito democrático. Coimbra:

Coimbra Editora, 2012.

PARFIT, Derek. On What Matters. Oxford: Oxford University Press, 2011, v. 1.

PULIDO, Carlos Bernal. El principio de proporcionalidad y los derechos fundamentales. $3^{\text {rd }}$ edn. Madrid: Centro de Estudios Políticos y Constitucionales, 2007.

RAWLS, John. Political Liberalism. New York: Columbia University Press, 1993.

Two Concepts of Rules. The Philosophical Review, n. 64, p. 3-32, 1955.

RAZ, Joseph. Is There a Reason to Keep Promises? Columbia Public Law, Research Paper n.12-320; Oxford Legal Studies Research Paper No. 62/2012. Available at SSRN: http://ssrn.com/abstract $=2162656$ or http://dx.doi.org/10.2139/ssrn.2162656 (October 16, 2012).

. Promises and Obligations. In: HACKER, P.M.S.; RAZ, Joseph (Eds.). Law, Morality and Society: Essays in Honor of H.L.A. Hart. Oxford: Clarendon Press, 1977.

RIVERS, Julian. Translator's Introduction. In: ALEXY, Robert. A Theory of Constitutional Rights. Oxford: Oxford University Press, 2002.

SCHLINK, Bernhard. Grundrechte als Prinzipien. Osaka University Law Review, n. 39, p. 41-58, 1992. . Proportionality in Constitutional Law: Why everywhere but here? Duke Journal of Comparative and International Law, n. 22, p. 291-302, 2012.

SHAPIRO, Scott. Legality. Cambridge: Harvard University Press, 2011.

SIECKMANN, Jan. Probleme der Prinzipientheorie der Grundrechte. In: CLÉRICO, Laura; SIECKMANN, Jan (Eds.). Grundrechte, Prinzipien und Argumentation: Studien zur Rechtstheorie Robert Alexys. Baden-Baden: Nomos, 2009.

SILVA, Virgílio Afonso da. Comparing the Incommensurable: Constitutional Principles, Balancing and Rational Decision. Oxford Journal of Legal Studies, n. 31, p. 273-301, 2011.

Grundrechte und gesetzgeberische Spielraum. Baden-Baden: Nomos, 2003.

SOUTER, David. Harvard's $359^{\text {th }}$ Commencement remarks. Harv. L. Rev, n. 124, p. 429-436, 2010.

STRAUSS, David. The Living Constitution. Oxford: Oxford University Press, 2010.

SUllivan, Kathleen M.. Two Concepts of Freedom of Speech. Harv. L. Rev. n. 124, p. 143-177, 2010.

TSAKYRAKIS, Stavros. Proportionality: An Assault on Human Rights? International Journal of Constitutional Law, n. 7, p. 468-493, 2009.

WEBBER, Grégoire C. N.. The Negotiable Constitution: On the Limitation of Rights. New York: Cambridge University Press, 2009. 
WILKINSON, J. Harvie. Cosmic Constitutional Theory. Oxford: Oxford University Press, 2012.

YOWELL, Paul. A Critical Examination of Dworkin's Theory of Rights. American Journal of Jurisprudence, n. 52, p. $93-137,2001$.

João Costa-Neto Brasília - DF - Brazil
joaocostanetolaoutlook.com

SENIOR LeCTURER IN LAW AT THE UnIVERsity OF BRASília. I 
